Reprod. Nutr. Dévelop., 1988, 28 (2 A), 265-274.

\title{
Pinealectomy, ovarian activity and vitellogenin levels in the catfish, Heteropneustes fossilis (Bloch), exposed to various combinations of photoperiods
}

S. K. GARG

\author{
Department of Zoology \\ Haryana Agricultural University, \\ Hisar 125004, India.
}

Summary. To assess the role of the pineal gland in the regulation of ovarian activity, female catfish were exposed to various combinations of photoperiods during the postspawning period of the annual reproductive cycle. Ovarian recrudescence and vitellogenin synthesis were accelerated after pinealectomy in catfish maintained under short photoperiod (9L: 15D) at $25^{\circ} \mathrm{C}$. However, at $25^{\circ} \mathrm{C}$, under long (14L: 10D), equal (12L : 12D), very short (6L : 18D) photoperiods, or under continuous light (LL or $24 \mathrm{~h}$ light) or continuous darkness (DD or $24 \mathrm{~h}$ darkness), pinealectomy delayed ovarian recrudescence and suppressed vitellogenin synthesis. These results suggest that the pineal gland in catfish may be anti- or progonadal, depending on the daylength to which the fish are exposed. Furthermore, the existence of a circadian photosensitive phase was revealed under 9L : 15D where the progonadal effects of pinealectomy were observed.

\section{Introduction.}

The presence of cone-like photoreceptors in the pineal gland, which may be photoneuroendocrine cells, have been demonstrated by electron microscopy in several species of fish (Bergmann, 1971; Oguri and Omura, 1973 ; Herwig, 1976 ; McNulty and Nafpaktitis, 1977 ; van Veen et al., 1980 ; Omura and Ali, 1981), including the catfish (Garg, 1981). Some cells of the teleostean pineal appear to be secretory, and photoperiod has been shown to affect the morphology and the secretory-like elements of the fish pineal (Hafeez et al., 1978 ; McNulty, 1982). This organ therefore may be functioning as an endocrine gland and be involved in mediating the effects of light/dark cycles on several physiological processes, including reproduction (Matty, 1978; Ralph, 1978; de Vlaming and Olcese, 1981 ; Vivien-Roels, 1981).

The catfish, Heteropneustes fossilis, is a seasonal breeder and spawns during the monsoon season. Its annual ovarian cycle in the environs of Delhi (Lat. $28^{\circ} 35^{\prime} \mathrm{N}$ and Long. $77^{\circ} 12^{\prime} \mathrm{E}$ ) can be divided into four periods (i) preparatory (February through April), (ii) prespawning (May and June), (iii) spawning (July and August) and (iv) postspawning (September through) January) (Sundararaj, 1981). 
The annual reproductive cycle of the catfish seems to be related to seasonal fluctuations of environmental factors such as photoperiod, temperature and rainfall. In nature, ovarian weight increases rapidly during the prespawning period when the photoperiod and temperature are increasing, suggesting that these two factors may induce ovarian recrudescence. The ovaries attain maximal weight in the spawning period (fig. 1).

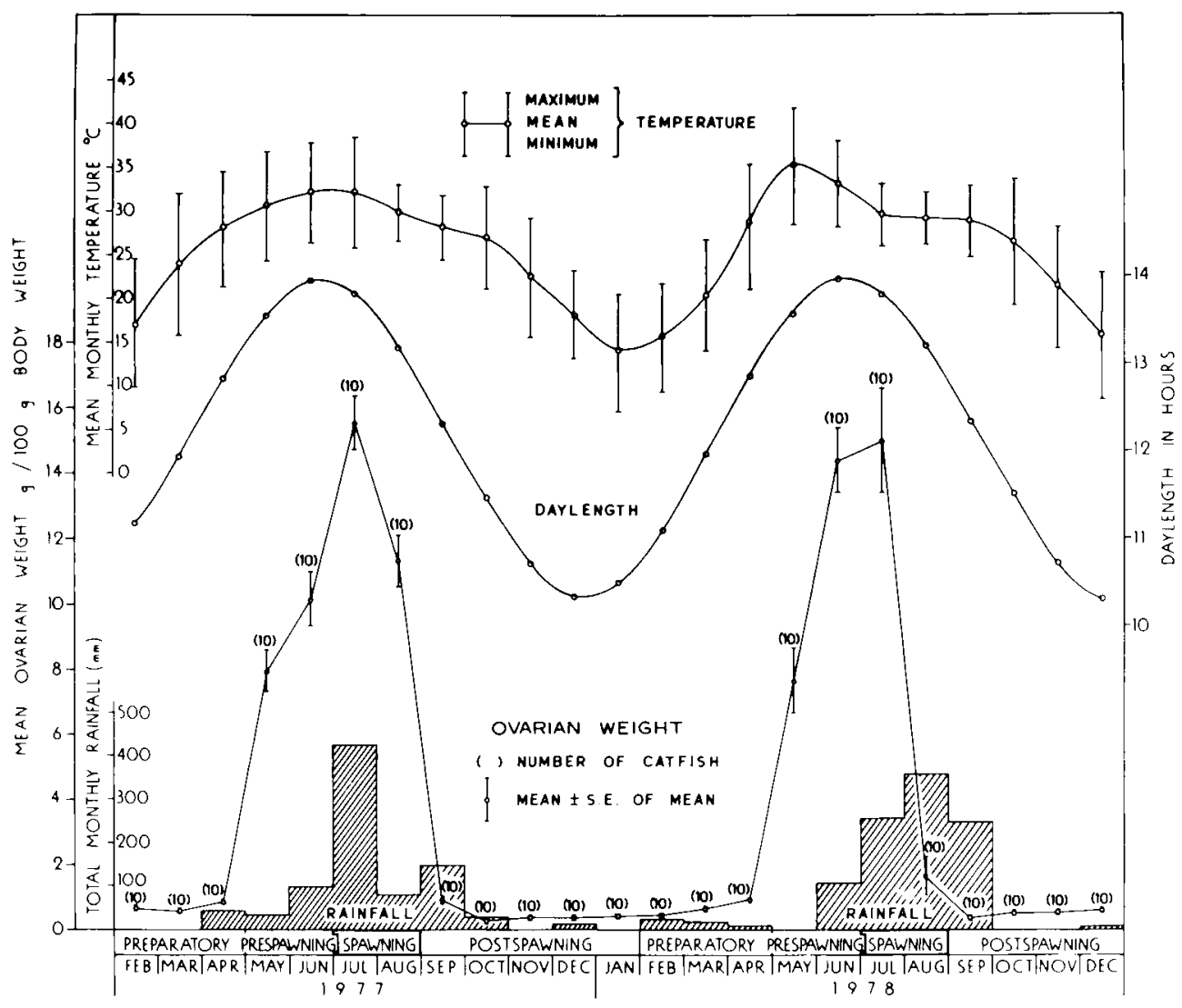

FIG. 1. - Seasonal changes in ovarian weight of the catfish, Heteropenustes fossilis, in relation to annual fluctuations in day length, temperature, and rainfall.

Studies on the role of photoperiod and temperature in the regulation of the ovarian cycle of the catfish have revealed that increasing or long days promote ovarian development, while a short photoperiod during the postspawning period suppresses ovarian activity (Vasal and Sundararaj, 1976 ; Garg, 1981).

The experiments of Garg $(1981,1987)$ on catfish have revealed that the pineal gland exerts both antigonadotropic and progonadotropic effects, depending on whether the photoperiod is short (9L: 15D) or long (14L: 10D). These studies have also shown that the pineal has no visible effects on gonadal activity during the preparatory, prespawning and spawning periods of the annual reproductive 
cycle. The present work further investigates the effects of pinealectomy on reproductive functioning in catfish, additional combinations of photocycles $(e . g$. $6 \mathrm{~L}: 18 \mathrm{D}, 12 \mathrm{~L}: 12 \mathrm{D}$ or $\mathrm{LL}$ or $\mathrm{DD}$ ) were investigated during the postspawning period, when the ovaries were totally regressed and the pineal considered to be maximally active.

\section{Material and methods.}

Collection and care of the fish. - Adult specimens of Heteropneustes fossilis were collected during December (winter) from the backwaters of the Jamuna River and its tributaries near Delhi when the gonads were fully regressed. After sexing, the females were allocated to glass aquaria $(61 \times 31.5 \times 31.5 \mathrm{~cm})$ and maintained in the laboratory at a temperature of $25 \pm 1{ }^{\circ} \mathrm{C}$ and on a lighting schedule of $12 \mathrm{~h}$ of light (08:00-20:00) alternating with $12 \mathrm{~h}$ of darkness (20:00-08:00) (12L: 12D). They were acclimated in the laboratory for 7 days before the experiments began and were fed on laboratory animal feed on alternate days. The aquarium water was renewed daily with water adjusted to laboratory temperature $\left(25^{\circ} \mathrm{C}\right)$. The experimental animals were always fed and the water replenished in all the aquaria during the light period, except for the fish kept under dark conditions, where feeding and changing of water were done in the dark using a dim red light.

Illumination. - Light-proof glass aquaria (61 $\times 31.5 \times 31.5 \mathrm{~cm})$ were used to expose the fish to different photoperiodic regimes. The top of each aquarium was covered with a wooden lid, fitted with a 20 -watt Philips fluorescent cool daylight tube. The light intensity above the water surface was about 1000 lux. The fish subjected to continuous darkness (DD) were kept in black aquaria having lightproof lids, while those exposed to continuous light (LL) were kept in transparent aquaria. The duration of the photoperiod in each aquarium or chamber was regulated by time switches. The aquaria were stacked in chambers with doors which were painted black on the inside. The periods of light and darkness in the aquaria coincided with natural day and night, respectively.

Surgical procedures. - Pinealectomy and sham-operation were performed as described by Garg (1987). Infection in the operated fish was minimized by adding procaine penicillin in the aquarium water daily for 15 days, then on alternate days for a week, and later only occasionally.

Levels of alkali-labile phosphorus. - Nath and Sundararaj (1981) have demonstrated that estrogen (estradiol-17 $\beta$ ) causes the appearance of femalespecific lipophosphoprotein (vitellogenin) in the serum of $H$. fossilis. If pinealectomy alters reproductive activity, depending on the photoperiodic conditions, it is possible that the serum levels of the estrogen-dependent femalespecific lipophosphoprotein would also be affected. Therefore, at the time of autopsy, blood samples were collected, for the estimation of vitellogenin, from the caudal vein into $3-\mathrm{ml}$ tubes or drawn directly from the heart into $1-\mathrm{ml}$ 
tuberculin syringes fitted with a 24-gauge needle. Vitellogenin was estimated in the serum samples according to the methods of Wallace and Jared (1968) and Martin and Doty (1949) and expressed as alkali-labile phosphorus $(\mu \mathrm{g} / \mathrm{ml})$ of serum). It has been shown that the estimation of alkali-labile phosphorus is a reliable index of vitellogenin levels in catfish serum (see Nath and Sundararaj, 1981).

After bleeding, the catfish were weighed and then killed by decapitation. The ovaries were removed, weighed on a torsion balance and fixed for $18 \mathrm{~h}$ in Bouin's fixative for histological examination.

Transverse sections of the ovaries were cut at $7 \mu \mathrm{m}$ and stained in Ehrlich's hematoxylin and eosin. Following the technique of Sundararaj and Sehgal (1970), three types of primary oocytes were identified from the stained ovarian sections of $H$. fossilis on the basis of nuclear and cytoplasmic characteristics : primary oocytes (diameter 50-120 $\mu \mathrm{m}$ ), the non-yolky oocytes present in the ovary at all seasons of the year (stage 1); primary oocytes (diameter 190-350 $\mu \mathrm{m}$ ) characterized by the presence of a ring of cortical alveoli, an indication of the onset of vitellogenesis (stage II); and primary oocytes (diameter 600-750 $\mu \mathrm{m}$ ), fully-formed yolky oocytes (stage III).

Surgically operated as well as sham-operated females were subjected to various combinations of photoperiods at $25^{\circ} \mathrm{C}$ for 80 days to study the effects of pinealectomy and sham-operation on ovarian activity and vitellogenin levels; the catfish were subjected to experimental treatments 12 to $18 \mathrm{~h}$ after surgery. The fish killed at the beginning of the experiments served as the initial controls.

Statistical analysis. - To compare the data, ovarian weights (GSI : wet gonad weight expressed as a percentage of wet body weight) were calculated on a $100 \mathrm{~g}$ body weight basis. The data were analysed by analysis of variance (ANOVA) and the group means were compared using the LSD test for the various parameters studied.

\section{Results.}

The effects of pinealectomy and sham operation were observed in catfish exposed to short photoperiod (9L: 15D), long (14L: 10D), very short (6L : 18D) or equal (12L : 12D) photoperiod and also to continuous light (LL) or continuous darkness (DD) at $25^{\circ} \mathrm{C}$ during the postspawning period.

The initial control catfish during this period of the reproductive cycle had fully regressed ovaries (GSI $=0.52$ ) containing only oogonia and stage I primary oocytes. Alkali-labile phosphorus (vitellogenin) could not be detected in the serum.

Continuous darkness (DD). - Exposure of the catfish to continuous darkness for 80 days did not inhibit normal ovarian development in the shamoperated controls. Ovarian recrudescence, however, was very slow in the pinealectomized groups and thus the GSI was significantly lower $(P<0.05)$ than that of the sham-operated controls (fig. 2). The vitellogenin levels in the serum of 
pinealectomized fish were also lower $(\mathrm{P}<0.05)$ than the controls, resulting in the formation of significantly fewer yolky oocytes $(P<0.05)$ in this group (table 1 ).

$6 \mathrm{~L}: 18 \mathrm{D}$. - Ovarian recrudescence under $6 \mathrm{~L}: 18 \mathrm{D}$ was very slow in the controls, and pinealectomy further suppressed vitellogenin synthesis and ovarian development $(P<0.05)$ (fig. 2). Histological sections revealed that the ovaries of
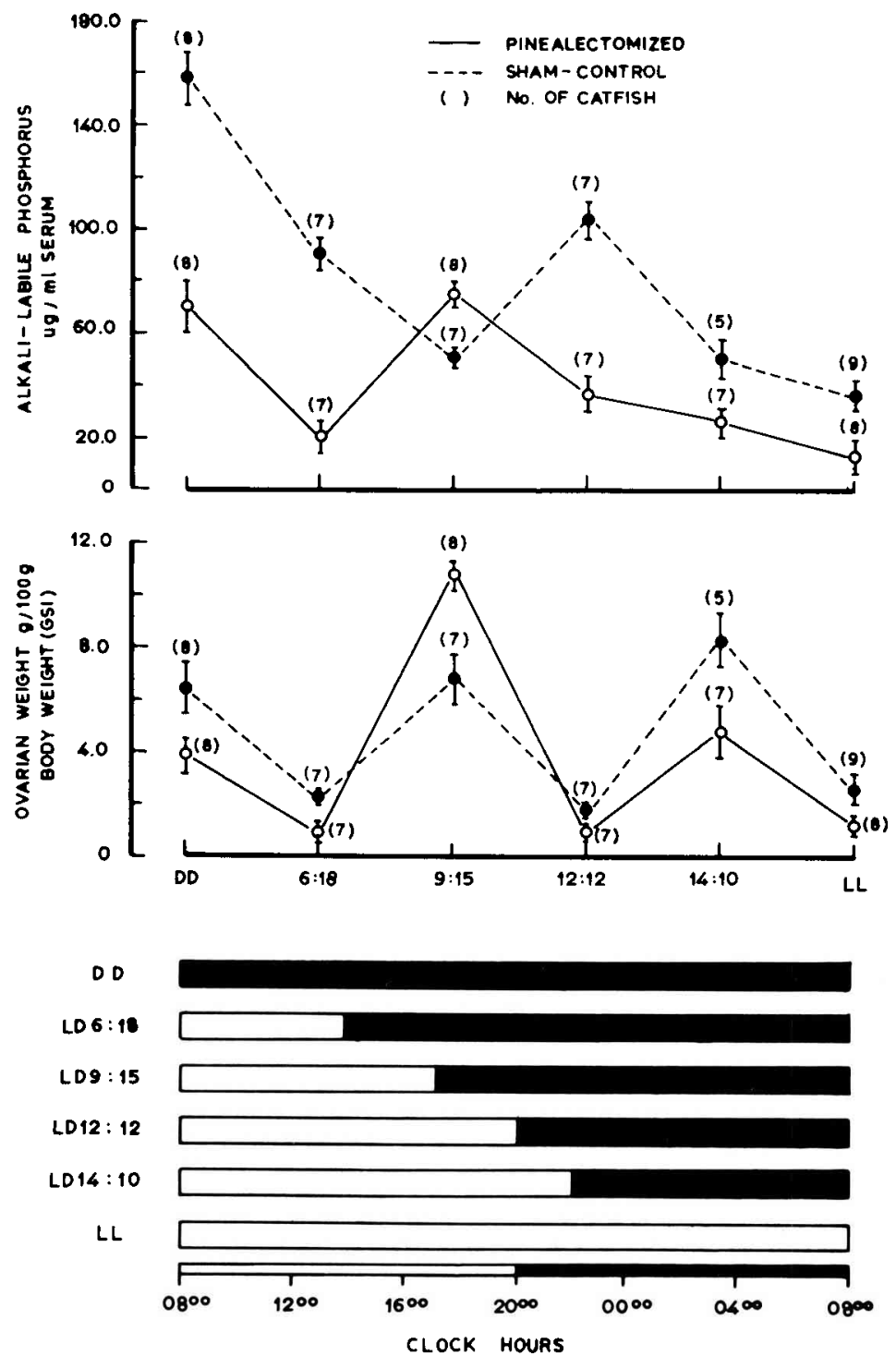

FIG. 2. - Ovarian weights (GSI) and vitellogenin levels in sham-operated and pinealectomized catfish exposed to continuous darkness (DD), very short photoperiod (6L: 18D), short photoperiod (9L : 15D), equal photoperiod (12L : 12D), long photoperiod (14L : 10D) and continuous light (LL) at $25{ }^{\circ} \mathrm{C}$ during the postspawning period.

$00^{\circ \circ}=$ midnight (Indian Standard Time). 
the pinealectomized fish contained only stage I primary oocytes, while the ovaries of the sham control had, in addition, oocytes from both stage II (vitellogenic) and stage III (yolky).

$9 L: 15 D$. - Ovarian activity of catfish exposed to this photoperiod was suppressed during the postspawning period. However, pinealectomy reversed the inhibitory effects of the photoperiod. At the end of 80 days of treatment there was a significant increase in the GSI and the vitellogenin levels $(P<0.05)$ in the pinealectomized fish compared to those of the sham-operated controls (fig. 2).

Ovarian histology indicated that the pinealectomized fish had a higher $(P<$ 0.05) percentage of stage III yolky oocytes compared to the sham-operated controls (table 1).

\section{TABLE 1}

Effects of sham-operation and pinealectomy on the ovarian histology of the catfish, Heteropneustes fossilis exposed to various photoperiods during the postspawning period for 80 days.

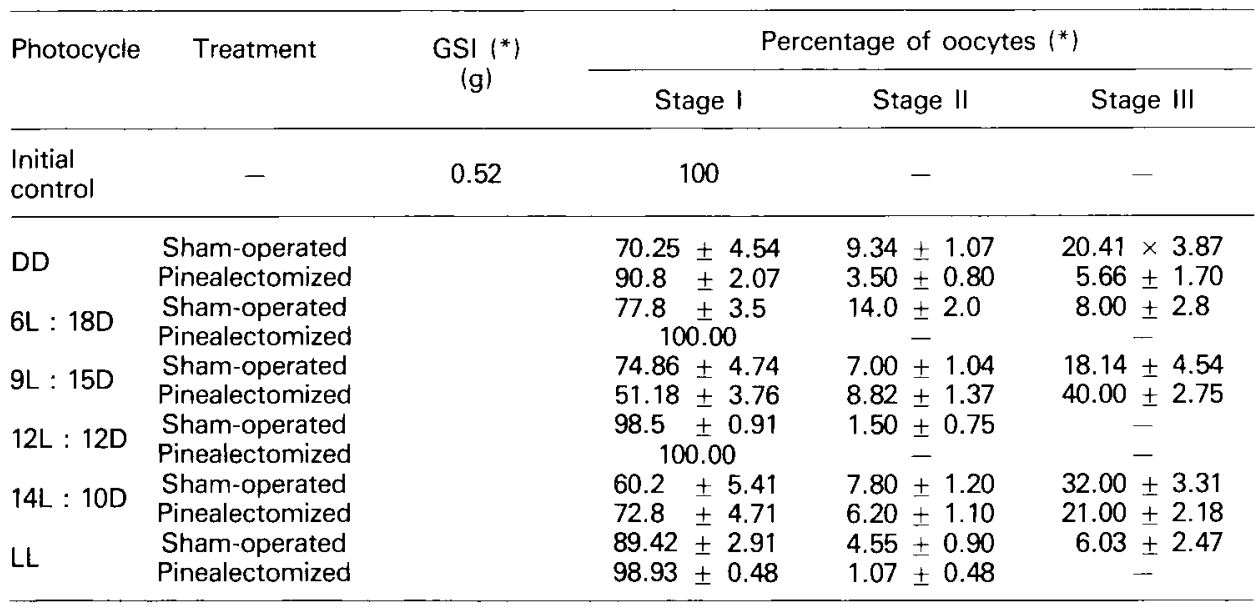

(*) Mean \pm S.E. of mean.

$12 L: 12 D$. - The GSI and the vitellogenin levels in sham-operated controls were significantly higher $(P<0.05)$ compared to the pinealectomized fish (fig. 2$)$. Ovarian histology showed that the pinealectomized fish had only stage I oocytes $(100 \%)$, whereas the ovaries of the sham-operated controls also had stage II vitellogenic oocytes (table 1 ).

14L: 10D. - Exposure of the catfish to a long photoperiod accelerated vitellogenin synthesis and ovarian development ; however, pinealectomy blocked the stimulatory effects of long photoperiod. Therefore, the GSI and vitellogenin levels in pinealectomized catfish were significantly lower $(P<0.05)$ compared to the sham-operated controls (fig. 2). Ovarian histology revealed that the pinealectomized fish had a significantly lower percentage of stage II and stage III $(P<0.05)$ oocytes compared to the sham-operated controls (table 1 ). 
Continuous light (LL). - Under this light cycle the GSI and the vitellogenin levels in the pinealectomized group also remained significantly lower $(P<0.05)$ than those of the sham-operated controls. Histological examination showed that the ovaries of the controls had both stage II (vitellogenic) and stage III (yolky) oocytes, while yolky oocytes were altogether absent in the pinealectomized fish (table 1).

A review of the results of the different photoperiods indicates that the GSI and the vitellogenic levels of pinealectomized fish under $9 L: 15 D$ were significantly higher than in the sham-operated controls, while under all other photoperiods the GSI and vitellogenic levels in the experimental groups remained significantly lower than in their respective controls.

\section{Discussion.}

Experiments involving pinealectomy have provided evidence for both the progonadal and the antigonadal effects of the pineal on ovarian activity and on vitellogenin levels in catfish. Ovarian activity was suppressed in catfish exposed to a short photoperiod (9L: 15D) during the postspawning period (Vassal and Sundararaj, 1976). However, under these conditions, pinealectomy promoted vitellogenin synthesis and ovarian recrudescence. The progonadal effects of pinealectomy under a short photoperiod in the present study are consistent with those reported for other teleosts (Fenwick, 1970b; de Vlaming and Vodicnik, 1978 ; Urasaki, 1973 ; de Vlaming, 1975 ; Sagi et al., 1983). However, these results are not in agreement with those of Day and Taylor (1983) who did not observe that pinealectomy had any effect on the ovaries of Fundulus heteroclitus exposed to 9L : 15D during different phases of the ovarian cycle. Recently, Hontela and Peter (1980) also reported that pinealectomy promoted a daily cycle in serum gonadotropin levels in goldfish kept under short photoperiod (8L : 16D) at $21{ }^{\circ} \mathrm{C}$ in the spring, while no such daily cycle in serum GTH levels was detected in the control fish kept under similar photothermal conditions. Thus, in mature fish kept under short photoperiod at warm temperature, pinealectomy induced gonadal recrudescence by promoting a daily cycle in the serum gonadotropin levels (Hontela and Peter, 1980). Therefore, higher vitellogenin levels in the pinealectomized catfish may be attributed to increased secretion or to the presence of a daily gonadotopin cycle under short photoperiodic conditions.

Increasing daylengths promote ovarian development in catfish (Vasal and Sundararaj, 1976 ; Garg, 1981), therefore the pineal may exert a progonadal effect in these fish under long photoperiod (14L: 10D). Even under continuous light, continuous darkness, $12 \mathrm{~L}: 12 \mathrm{D}$ or $6 \mathrm{~L}: 18 \mathrm{D}$ the pineal exercises a progonadal influence since vitellogenin synthesis is suppressed and ovarian recrudescence delayed in pinealectomized catfish. The progonadal effects of the pineal under the long photoperiod described here are in accord with those reported in other fishes (Urasaki, 1972a, 1973 ; de Vlaming, 1975 ; de Vlaming and Vodicnik, 1977, 1978 ; Vodicnik et al., 1978). However, Sagi et al., (1983) did not observe any effects of 
pinealectomy on the ovaries of Liza ramada exposed to long photoperiodic conditions. While the results of the present study on the effects of pinealectomy on catfish gonads under LL confirm those of Urasaki (1972a, b) in medaka, the data obtained on catfish kept under DD are contrary to those reported by that author (1972b).

From these findings it may be concluded that in catfish exposed to a photoperiod shorter (e.g. 6L : 18D or DD) or longer (e.g. 12L : 12D, 14L : 10D or LL) than 9L:15D, pinealectomy suppresses the synthesis of vitellogenin and ovarian development. This may imply that a circadian photosensitive phase exists, within 6 to $12 \mathrm{~h}$ after the onset of the photophase, during which vitellogenin synthesis and ovarian recrudescence occur as a consequence of pinealectomy. No comparable information on the role of the pineal gland in reproduction is available for any of the fish species experimented on.

The mechanism or pathways involved in the measurement of such rhythms under various photoperiods is obscure. However, according to Bünning (1960, 1969) the photoperiodic eff:ciency of any given light/dark cycle depends primarily on which portion of an underlying circadian sensitivity rhythm is illuminated. This hypothesis suggests a circadian rhythm of cellular functioning consisting of two half-cycles, each lasting about $12 \mathrm{~h}$ and one of which requires light (the photophil phase) while the other requires darkness (the scotophil phase). In many vertebrates, including fishes (Gern et al., 1978 ; Owens and Ralph, 1978 ; VivienRoels et al., 1981), synthesis of the pineal hormone, melatonin, and its concentration vary daily and are greatly affected by environmental lighting conditions. Therefore, the changing rhythmic pattern of melatonin formation or of its release under different photoperiods may be the physiological mechanism for transducing photic information into humoral signals that are eventually transmitted to the neuroendocrine gonadal axis.

Although these studies provide information regarding the existence of a photosensitive phase, further studies on night interruption using skeleton photoperiods and/or resonance lighting might be more useful in arriving at a final conclusion.

In catfish, estrogen-dependent female-specific yolk protein-vitellogenin levels increased or decreased as a result of pinealectomy, depending on the photoperiod to which the fish were exposed : this indicates that pinealectomy affected plasma sex steroids, possibly altering the rate of gonadotropin secretion. Our results demonstrate that the pineal effects in catfish may be mediated through an influence on the hypothalamo-hypophyseal ovarian axis. However, further investigations of gonadotropin levels in catfish are needed to support the above hypothesis.

Furthermore, the amplitude of the vitellogenin titers indicates greater variation under different photoperiods. Thus, pinealectomy may affect steroidogenesis differently, leading to variations in the synthesis of vitellogenin, its release from the liver or its incorporation into the growing oocytes under different photoperiods. However, more studies are needed to determine this. 
Résumé. Epiphysectomie, activité ovarienne et niveau de vitellogénıne chez le poissonchat, Heteropneustes fossilis (Bloch), soumis à des rythmes photopériodiques divers.

Pour déterminer le rôle de l'épiphyse dans la régulation de l'activité ovarienne, des poissons-chats (Heteropneustes fossilis) ont été soumis à des régimes photopériodiques divers après la période annuelle de frai. Chez les poissons maintenus en photopériode courte $(9 \mathrm{~L} / 15 \mathrm{~N})$ et à $25^{\circ} \mathrm{C}$, la réactivation de l'ovaire et la synthèse de vitellogénine ont été accélérées par l'épiphysectomie. Au contraire, sous tous les autres rythmes photopériodiques (L/N : 24/0,14/10,12/12, 6/18 ou 0/24) l'épiphysectomie a un effet inverse, retardant la reprise de l'activité ovarienne et de la synthèse de vitellogénine. Ainsi, chez le poisson-chat l'épiphyse peut avoir un effet pro- ou anti-gonadotrope selon les conditions d'éclairement. De plus, le fait que l'effet progonadotrope n'est observé que sous $9 \mathrm{~L} / 15 \mathrm{~N}$ indique l'existence d'une phase circadienne de photosensibilité.

\section{References}

BERGMANN G., 1971. Elektronemikroskopische untersuchungen am pinealorgan von Pterophyllum scalare Cuv. et Val. (Cichlidae, Teleostei). Z. Zel/forsch., 119, 257-288.

BÜNNING E., 1960. Circadian rhythms and time measurement in photoperiodism. Cold. Spring Harbor Symp. Quant. Biol., 25, 249-256.

BÜNNING E., 1969. Common features of photoperiodism in plants and animals. Photochem. Photobiol., 9, 219-228.

COLLIN J. P., OKSCHE A., 1981. Structural and functional relationships in the non-mammalian pineal organ. In R. J. REITER, The pineal organ, Vol. 1. Anatomy and biochemistry. CRC Press Inc., Boca Raton, F1, 27-67.

DAY J. A., TAYLOR M. H., 1983. Environmental control of the annual gonadal cycle of Fundulus heteroclitus L. : The pineal organ and eyes. J. exp. Zool., 227, 453-458.

DE VLAMING V. L., 1975. Effects of pinealectomy on gonadal activity in the cyprinid teleost, Notemigonous crysoleucas. Gen. comp. Endocrinol., 26, 34-49.

DE VLAMING V. L., OLCESE J., 1981. The pineal and reproduction in fish, amphibians and reptiles. In R. J. REITER, The pineal gland, Vol. II. Reproductive effects. CRC Press, Boca Raton, Florida, 1-29.

DE VLAMING V. L., VODICNIK M. J., 1977. Effects of pinealectomy on pituitary gonadotrophs, pituitary gonadotropin potency and hypothalamic gonadotropin releasing activity in Notemigonus crysoleucas. J. Fish Biol., 10, 73-86.

DE VLAMING V. L., VODICNIK M. J., 1978. Seasonal effects of pinealectomy on gonadal activity in the goldfish, Carassius auratus. Biol. Reprod., 19, 57-63.

FENWICK J. C., 1970a. Demonstration and effect of melatonin in fish. Gen. comp. Endocrinol., 14, 84-97.

FENWICK J. C., 1970b. The pineal organ : photoperiod and reproductive cycles in the goldfish, Carassius auratus L. J. Endocrinol., 46, 101-111.

GARG S. K., 1981. Experimental studies on the role of the pineal organ in the regulation of reproductive cycles in the catfish, Heteropneustes fossilis (Bloch). Ph. D. Thes. Univ. Delhi, Delhi, India, 139.

GARG S. K., 1987. Seasonal effects of pinealectomy on testicular recrudescence and secretory activity of seminal vesicles in the catfish Heteropneustes fossilis (Bloch). J. Fish Biol., 30. 377-387.

GERN W. A., OWENS D. W., RALPH C. L., 1978. Plasma melatonin in the trout, Day-night changes demonstrated by radioimmunoassay. Gen. comp. Endocrinol., 34, 453-458.

HAFEEZ M. A., WAGNER H., QUAY W. B., 1978. Mediation of light-induced changes in pineal receptor and supporting cell nuclei and nucleoli in steelhead trout, Salmo gairdneri. Biochem. Photobiol., 28, 213-218. 
HERWIG H. J., 1976. Comparative ultrastructural investigations of the pineal organ of the blind cave fish, Anoptichthys jordani, and its ancestor the eyed river fish, Astyanax mexicanus. Cell Tissue Res., 167, 297-324.

HONTELA A., PETER R. E., 1980. Effects of pinealectomy, blinding, and sexual condition on serum gonadotropin levels in the goldfish. Gen. comp. Endocrinol., 40, 168-179.

MARTIN J. B., DOTY D. M., 1949. Determination of inorganic phosphate. Anal. Chem., 21, 965967.

MATTY A. J., 1978. Pineal and some pituitary hormone rhythms in fish. In J. E. THORPE, Rhythmic activity of fishes. Acad. Press London, New York, San Francisco, 21.

McNULTY J. A., 1982. The effects of constant light and constant darkness on the pineal organ of the goldfish, Carassius auratus. J. exp. Zool., 219, 29-37.

McNULTY J. A., NAFPAKTITIS H. G., 1977. Morphology of the pineal complex in seven species of lantern fishes (Pisces: Myctophidae). Am. J. Anat., 150, 509-530.

NATH P., SUNDARARAJ B. I., 1981. Isolation and identification of female-specific serum lipophosphoprotein (vitellogenin) in the catfish. Heteropneustes fossilis (Bloch). Gen. comp. Endocrinol., 43, 184-190.

OGURI M., OMURA Y., 1973. Ultrastructure and functional significance of the pineal organ of teleosts. In W. CHAVIN, Responses of fish to environmental changes. Charles C. Thomas, Springfield, 412-434.

OMURA Y., ALI M. A., 1981. Ultrastructure of the pineal organ of the killifish, Fundulus heteroclitus, with special reference to the secretory function. Cell Tissue Res., 219, 355-369.

OWENS D. W., RALPH C. L., 1978. Nonrelationship between plasma melatonin and background adaptation in the rainbow trout (Salmo gairdneri). Gen. comp. Endocrinol., 34, 459-467.

RALPH C. L., 1978. Pineal control of reproduction: Nonmammalian vertebrates. Prog. Reprod. Biol., 4, 30-50.

SAGI G., ABRAHAM M., HILGE V., 1983. Pinealectomy and ovarian development in the grey mullet, Liza ramada. J. Fish Biol., 23, 339-345.

SUNDARARAJ B. I., 1981. Reproductive physiology of teleost fishes. A review of present knowledge and needs for future research. ADCP/REP/81/16 FAO of the United Nations, Rome, p. 82.

SUNDARARAJ B. I., SEHGAL A., 1970. Short and long-term effects of imposition of total darkness on the annual ovarian cycle of the catfish, Heteropneustes fossilis (Bloch). J. Interdiscip. Cycle Res., 1, 291-301.

URASAKI H., 1972a. Role of the pineal gland in gonadal development in the fish, Oryzias latipes. Annot. zool. Japon, 45, 152-158.

URASAKI H., 1972b. Effect of pinealectomy on gonadal development in the Japanese killifish (Medaka), Oryzias latipes. Annot zool. jap., 45, 10-15.

URASAKI H., 1973. Effects of pinealectomy and photoperiod on oviposition and gonadal development in the fish, Oryzias latipes. J. exp. zool., 185, 241-246.

VASAL S., SUNDARARAJ B. I., 1976. Response of the ovary in the catfish. Heteropneustes fossilis (Bloch), to various combinations of photoperiod and temperature. J. exp. zool., 197, 247264.

van VEEN T. H., EKSTROM P., BROG B., MOLLER M., 1980. The pineal complex of the threespined stickleback, Gasterosteus aculeatus L. A light-electron microscopic, and fluorescence histochemical investigation. Cell Tissue Res., 209, 11-28.

VIVIEN-ROELS B., 1981. Pineal control of reproduction in non-mammalian vertebrates. In OKSCHEA., PEVET P., Elsevier/North-Holland biomed. Press, 315-334.

VIVIEN-ROELS B., PEVET P., DUBOIS M. P., ARENDIT J., BROWN G. M., 1981. Immunohistochemical evidence for the presence of melatonin in the pineal gland, the retina and the harderian gland. Cell Tissue Res., 217, 105-115.

VODICNIK M. J., KRAL R. E., de VLAMING V. L., CRIM R. W., 1978. The effects of pinealectomy on pituitary and plasma gonadotropin levels in Carassius auratus exposed to various photoperiod-temperature regimes, J. Fish Biol, 12, 187-196.

WALLACE R. A., JARAD D. W., 1968. Studies on the amphibian yolk VII. Serum phospho-protein synthesis by vitellogenic females and estrogen-treated males of Xenopus laevis. Can. J. Biochem., 46, 953-959. 